\title{
CLASSIFICATION OF THE SOURCE MATERIAL OF TOBACCO VARIETIES CULTIVATED IN THE CENTRAL PART OF THE FOREST-STEPPE OF UKRAINE BY THE MULTIVARIATE STATISTICS METHOD
}

\section{Leonova Katerina ${ }^{1}$ Morgun Andriy ${ }^{2}$}

DOI: https://doi.org/10.30525/978-9934-571-89-3_99

Tobacco is an important technical crop. Until recently, it was one of the most profitable crops in Ukraine thanks to the highly productive domestic varieties, with a profitability level of 28-40\%. However, over the years of independence of our state, there has been a tendency towards a decline in tobacco production. The main reason of the tobacco production decline is the reduction of cultivating areas in the Zakarpatti, Prydnistrovyi and the loss of a unique cultivation zone in the Crimea. According to the official statistics, tobacco production in Ukraine serves the industry needs for only $0,15 \%$. The work of tobacco factories depends entirely on the import of raw materials from abroad [1, p. 23].

The strategic task of the tobacco industry is to increase the volumes of own tobacco production, which is possible only due to the introduction of new competitive varieties of domestic breeding with the improved quantitative and qualitative productivity indices $[4$, p. 78$]$.

Therefore, the main task of the crop breeders is to create the early-ripening, high-yielding varieties and hybrids of tobacco with high quality of raw materials, which depend primarily on the genetic potential of the source material and conditions of cultivation, for cultivating in the conditions of the Central ForestSteppe of Ukraine [2, p. 119].

The aim of the research was to evaluate the tobacco source material as a complex of major morphological and biological features (plant height, number of leaves, leaf size (length and width), yields of raw materials and the growing season duration) and to group the genetically close varieties into separate clusters, which will enable to

\footnotetext{
${ }^{1}$ Research Station of Tobacco Growing

of the National Academy of Agricultural Sciences of Ukraine, Ukraine

${ }^{2}$ Research Station of Tobacco Growing

of the National Academy of Agricultural Sciences of Ukraine, Ukraine
} 
predict the transgressive segregation level of the hybrid progeny by the genetically different forms crossing [3, p. 67].

Experimental researches were carried out at the Research Station of Tobacco Growing of the National Academy of Agricultural Sciences of Ukraine, (Uman, Cherkasy region) during 2017-2018. The source material for the research was 26 varieties of tobacco of various ecological and geographical origins.

Using the STATISTICA 10.0 computer program, all the varieties were divided into six clusters.

The first cluster includes two varieties: Krupnolystyi 52 (C. 19) and Gostrolyst Rubin (C. 21) (Figure 1). These varieties are similar to each other for the morphological characteristics: the height of plants - 254-268 cm (very tall plants), the number of leaves $-22-24$, the leaf length $-54-55 \mathrm{~cm}$ and the leaf width $33-34 \mathrm{~cm}$. The yield of raw material of the variety Krupnolystyi 52 (C. 19) was 4,1 t/ha, and Gostrolyst Rubin (C. 21) - 5,4 t/ha. The growing season duration was within 102-114 days.

The second cluster was formed from six varieties: American 1 (C. 12), American 165 (C. 13), Trapezond Beregovyi (C. 17), Trapezond Platana (C. 18), Virginia Joyner (C. 24) and Samsun Krasnodar (C. 26). All the varieties are late ripening with a vegetation period of 114-120 days. The height of the plant varieties of this cluster was within the range of $163-180 \mathrm{~cm}$ (medium-grown plants). In the four varieties, namely: American 1 (C. 12), American 165 (C. 13), Virginia Joyner (C. 24) and Samsun Krasnodar (C. 26) the number of leaves was in the range of 20-25, in the two varieties Trapezond Platana (C. 18) and Trapezond Beregovyi (C. 17) - 16-17, the leaf length varied within 42-48 cm, width $-24-29 \mathrm{~cm}$. In the Samsun Krasnodar variety the leaf length was $37 \mathrm{~cm}$ and the width $-23 \mathrm{~cm}$. The yield of raw materials of these varieties was at the level of 2,3-2,4 t/ha, with the exception of two ones, namely: Trapezond Plata (C. 18) and Trapezond Beregovyi (C. 17), which indices were 1,3 and $1,9 \mathrm{t} / \mathrm{ha}$, respectively.

The third cluster was formed by the varieties Berley 38 (C. 6) and Berley 46 (C. 7). The plant height of these varieties was within the range of $158-163 \mathrm{~cm}$ (shortgrowing. The number of leaves was $21-23$. The leaf length is $53-54 \mathrm{~cm}$ and the width is $32-34 \mathrm{~cm}$. The yield of the raw material is 3,7 and $4,0 \mathrm{t} / \mathrm{ha}$. The average vegetation period over the research years in both varieties was 104 days.

The fourth cluster included six varieties of tobacco: Ternopilskyi Perspektyvnyi (C. 4), Berley 9 (C. 8), Trapezond (C. 10), Sobolchskyi 33 (C. 11), Berley 7433 (C. 14) and Samsun Crimea (C. 25). Four varieties were distinguished as the tall ones: Ternopilskyi Perspektyvnyi (C. 4), Berley 9 (C. 8), Trapezond (C. 10) and Samsun Crimea (C. 25) with the indices of 188, 195, 199, 193 and $200 \mathrm{~cm}$ respectively, and one as a medium-grown variety - Berley 7433 (C. 14) $-178 \mathrm{~cm}$. The number of leaves was 23-25 in such four varieties as Ternopilskyi Perspektyvnyi (C. 4), Berley 9 (C. 8), Trapezond (C. 10) and Sobolchskyi 33 (C. 11) and the varieties Samsun Crimea (C. 25) and Berley 7433 (C. 14) had 15-19 leaves. The leaf length in all the varieties varied in the range of $46-57 \mathrm{~cm}$ and the width was $27-32 \mathrm{~cm}$. The yield of raw materials in these varieties was at the level of 
3,0-3,7 t/ha, except for the variety Berley 7433 (C. 14), which index was 4,5 t/ha. The growing season duration was 100-105 days.

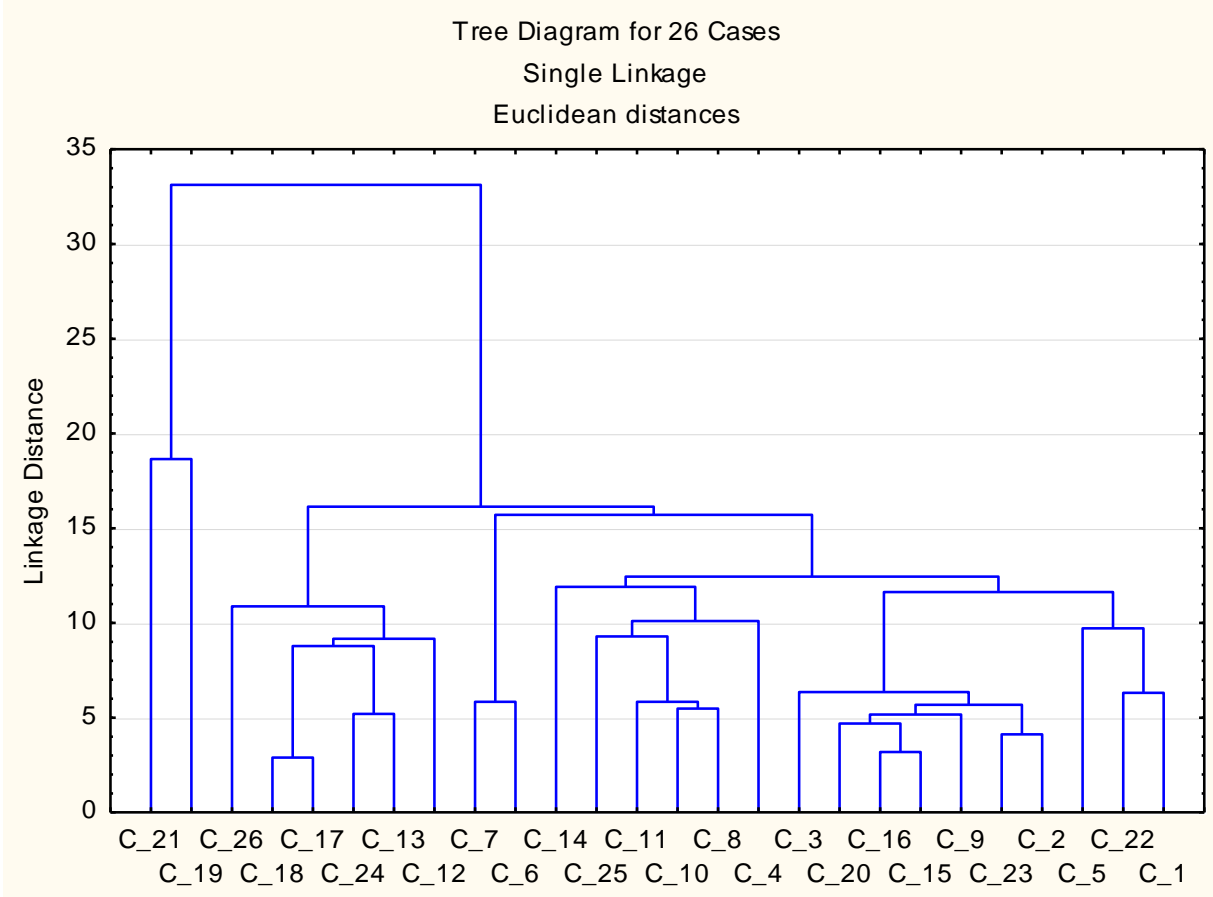

\section{Figure 1. Euclidean distances between the tobacco varieties of different clusters (average for 2017-2018)}

Seven tobacco varieties are typical for the fifth cluster, such as: Ternopilskyi 7 (C. 2), Ternopilskyi 14 (C. 3), Spectr (C. 9), Berley White (C. 15), Bravyi 200 (C. 16), Gostrolyst Giant (C. 20) and Virginia Joyner (C. 24). All tobacco varieties were very tall, with a plant height of 209-224 cm except for the Virginia Joyner variety (C. 24), which height was $177 \mathrm{~cm}$ (medium-grown). The number of leaves varied within 20-24. The leaf length for all varieties was $54-57 \mathrm{~cm}$ and the width was $32-35 \mathrm{~cm}$. The Virginia Joyner variety (C. 24) was an exception with a leaf length of $47 \mathrm{~cm}$ and a width of $25 \mathrm{~cm}$. The growing season duration was 100-108 days, only by the variety Virginia Joyner (C. 24) 118 days. The high yield of raw materials was typical for the varieties: Bravyi 200 (C. 16), Gostrolyst Giant (C. 20) and Gostrolyst Yubileinyi New (C. 23) which indices were 5,3 and 5,6 t/ha, and the average yield was typical for the varieties Spectrum (C. 9), Ternopilskyi 7 (C. 2) and Berley White (C. 15) - 4,1, 4,2 and 4,9 t/ha, respectively. The varieties Virginia Joyner (C. 24) and Ternopilskyi 14 (C. 3) were less productive, with a yield of 2,3 and $3,6 \mathrm{t} / \mathrm{ha}$.

The sixth cluster was formed by the three varieties: Virginia 27 (C. 1), Temp 321 (C. 5), and Gostrolyst Yubileinyi New (C. 23). These varieties are morphologically similar. Plants of these varieties are tall, with a height of $203-215 \mathrm{~cm}$. The number of leaves was 22-25. The leaf length varied within $52-54 \mathrm{~cm}$, width $-32-35 \mathrm{~cm}$. The growing season duration of the varieties Virginia 27 (C. 1) and Temp 321 (C. 5) was 117-121 days and of the variety Gostrolyst Yubileinyi New (C. 23) - 102 days. 
According to the raw material yield, the Gostrolyst Yubileinyi New variety (C. 23) was the leader with an index of 5,6 t/ha. The varieties Temp 321 (C. 5) and Virginia 27 (C. 1) had the indices 3,6 and 4,2 t/ha respectively.

Thus, the conducted cluster analysis of the source material, based on a set of main features, enables early identification, distribution and selection of parent components of hybridization to create the new competitive domestic tobacco varieties in the early stages of the selection process.

\section{References:}

1. Byalkovska G. D. (2013). Kryza tiutiunnytstva ta shliakhy yii podolannia. [Tobacco crisis and ways to overcome it]. Stalyi rozvytok ekonomiky. Mizhnarodnyi naukovovyrobnychyi zhurnal [Sustainable Development of the Economy: International Science and Technology Magazine]. Vol. 2, pp. 23-29. (in Ukrainian)

2. Khomutova S. A. (2010). Ispol'zovanie gibridizatsii pri sozdanii skorospelogo iskhodnogo materiala i sortov tabaka [The use of hybridization in the creation of early source material and varieties of tobacco]. Sbornik nauchnykh trudov Vserossiyskogo nauchno-issledovatel'skogo instituta tabaka, makhorki i tabachnykh izdeliy [Collection of scientific works of the All-Russian Scientific Research Institute of Tobacco, shag and tobacco products]. Krasnodar, vol. 179, pp. 119-124. (in Russian)

3. Psareva E. N. (1969). Klassifikatsiya Nicotiana tabacum L. [Classification of Nicotiana tabacum L.]. Sbornik nauchno-issledovatelskich rabot VNII tabaka I makhorki [Proceeding of All Union Research Institute of Tobacco and Makhorka]. Krasnodar, vol. 154, pp. 67-72. (in Russian)

4. Kosmodemyanskiy V. N., Psareva E. N., Grebenkin A. P., Yakovu A. S., Vlasov V. I., Ivanova T. Z., Ruban E. V. (1974). Metodiki selektsionnoy raboty po tabaku i makhorke [Methods of breeding work on tobacco and shag]. Krasnodar, p. 78. (in Russian) 